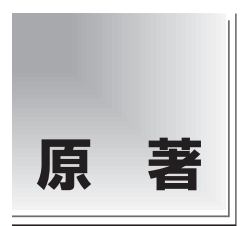

\section{Intravoxel incoherent motion による \\ 運動前後の筋肉毛細血管血流量の評価}

\author{
五月女華 ${ }^{1} \quad$ 小倉明夫 ${ }^{2} \quad$ 浅井歩実 ${ }^{3} \quad$ 藤生敦哉 $^{4}$ \\ ${ }^{1}$ 群馬県立県民健康科学大学診療放射線学部 (現 公立藤岡総合病院放射線室) \\ 2 群馬県立県民健康科学大学大学院 \\ ${ }^{3}$ 群馬県立県民健康科学大学診療放射線学部 (現 静岡市立静岡病院放射線技術科) \\ ${ }^{4}$ 群馬県立県民健康科学大学診療放射線学部(現 桐生厚生総合病院放射線科)
}

論文受付

2017 年 11 月 7 日

論文受理

2018 年 6 月 16 日

Code No. 261

\section{緒 言}

拡散強調画像 (diffusion weighted image: DWI) は体 内の水分子の拡散運動を信号化し, 現在臨床で有益な 生体情報を提供しているが, その中で特に拡散と灌流 が混在した不規則 (incoherent)なプロトンの動きを表 現するのが IVIM(intravoxel incoherent motion)であ
る. DWI でいくつかの異なる b 值を設定し，得られ た信号強度の対数をグラフにプロットすると $\mathrm{b}$ 值= 50-100 s/mm 以上でグラフは直線となるが b 值= 50-100 s/mm 以下で直線から乘離する (Fig. 1)。そ の乘離した領域を IVIM と呼び, IVIM における信号 強度は Le Bihan らの研究1) から, 次の式で求められる。

\title{
Capillary Blood Flow of Muscle Before and After the Exercise Used by Intravoxel Incoherent Motion
}

\author{
Hana Sotome, ${ }^{1 *}$ Akio Ogura, ${ }^{2}$ Ayumi Asai, ${ }^{3}$ and Atsuya Fuju ${ }^{4}$ \\ ${ }^{1}$ School of Radiological Technology, Gunma Prefectural College of Health Sciences (Current address: Department of \\ Radiology, Fujioka General Hospital) \\ ${ }^{2}$ Graduate School, Gunma Prefectural College of Health Sciences \\ ${ }^{3}$ School of Radiological Technology, Gunma Prefectural College of Health Sciences (Current address: Department of \\ Radiology, Shizuoka City Shizuoka Hospital) \\ ${ }^{4}$ School of Radiological Technology, Gunma Prefectural College of Health Sciences (Current address: Department of \\ Radiology, Kiryu Kosei General Hospital)
}

Received November 7, 2017; Revision accepted June 16, 2018

Code No. 261

\section{Summary}

Capillaries are the most basic and important blood vessel of the circulatory systems. The evaluation of the blood flow may contribute to many studies in future. We evaluated the capillary blood flow change of lower limb muscle over time before and after the exercise used by magnetic resonance imaging-intravoxel incoherent motion (MRI-IVIM) obtained perfusion information. Furthermore, we examined an association between the muscle pain after the exercise and the diffusion weighted image (DWI) indexes. DWI was imaged using multi-b values for a thigh and calf muscles. MRI was performed just after an exercise test, 3, 6, and 24 hours later, and the IVIM index and diffusion index were calculated. Furthermore, we interviewed the degree of the muscle ache 24 hours later. As a result, pseudo diffusion coefficient (D*) and f value as IVIM index increased after-exercise as compared with preexercise and decreased in 3 hours later. A similar tendency was found in the apparent diffusion coefficient and the diffusion coefficient as diffusion index. Furthermore, all indexes increased in after exercise from before exercise and decreased with time passed and increased again 24 hours later. In conclusion, IVIM could obtain capillary blood flow information, and it was suggested to contribute for sports medicine in future.

Key words: intravoxel incoherent motion (IVIM), muscle, exercise, diffusion weighted image (DWI), magnetic resonance imaging (MRI)

*Proceeding author 


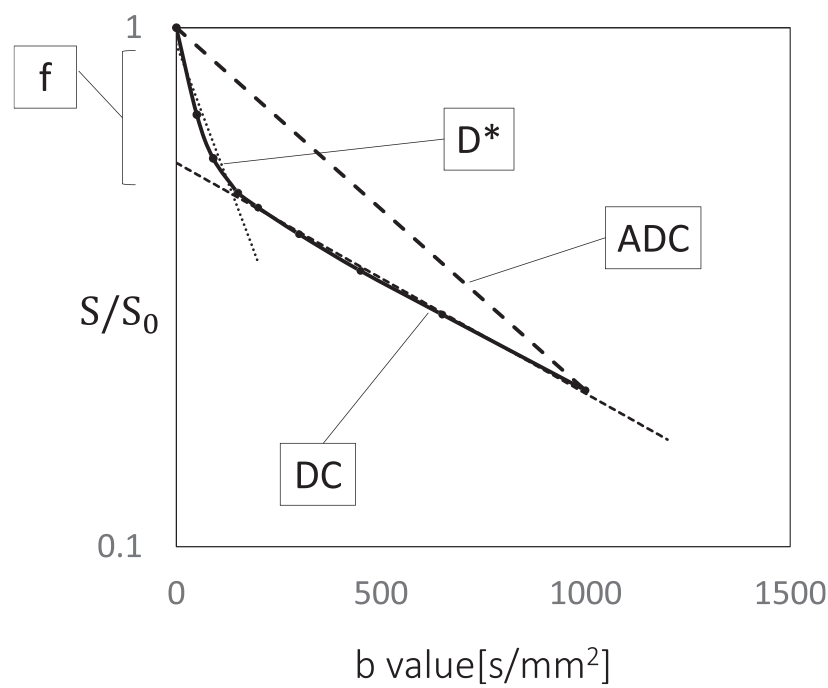

Fig. 1 The bi-exponential signal attenuation of biological body at multi-b values of DWI and the IVIM and DWI indexes. ADC: apparent diffusion coefficient

$S=S_{0} \cdot\left\{(1-f) \cdot \exp (-b \cdot D)+f \cdot \exp \left(-b \cdot D^{*}\right)\right\}$

ここで, f 1 1 1 ボクセル内の灌流の占める割合 (perfusion fraction), D は拡散部の拡散係数 (diffusion coefficient), $\mathrm{D}^{*}$ は灌流部の拡散係数 (pseudo diffusion coefficient)であり, 得られたグラフから算出すること が可能である (Fig. 1)。拡散係数は, 拡散の推測時間 内に抢ける目的成分の移動程度を表し，灌流は拡散に 比べて移動速度が速く， D* は D に比べて大きな值と なる、このため，小さな b 值を多く設定し信号収集す ることで拡散部分の情報を排除し, 灌流部の情報を得 ることが可能となり, 得られた指標を用いて灌流の評 価を行うことができる.

以上のことより，IVIM では造影剂を使用すること なく病変の細胞密度と組織灌流の評価が可能であり, これらの指標は病変鑑別において有用であると期待さ れている. Ichikawa らの肝病変における IVIM の研 究では悪性腫瘍の D および D*は，良性腫瘍に比べて 小さな值となることや D が局所肝病変の識別におい て信頼性が高いことが報告されている21. 近年では, IVIM は肝臟における悪性腫瘍の鑑別のほか, 腎不全 症の鑑別や前立腺がんの評価, 脳腫瘍の評価, 乳がん, 子宮頸がん，脺藏がんなど多くの臨床応用の報告があ $ろ^{3 \sim 8)}$.

ところで, 運動による筋肉疲労や筋肉痛を起こすプ ロセスは現在でも明確ではないが, 筋肉内の毛細血管 が関与していることは明らかであり，毛細血管血流 は，運動によって増加することがわかっている ${ }^{9.10)}$.

そのため本研究では IVIM を使用して, 運動前後の 筋肉内の毛細血管血流量の変化を評価し, 更に運動後
の筋肉痛と DWI で得られる各指標との関係を評価す ることで今後のスポーツ医学への適応を検討した。

\section{1. 方 法}

\section{1-1 撮像対象者および撮像方法}

本研究の施行にあたり, 事前に当該倫理委員会の承 認を得た，撮像対象者は, 公募後, 同意を得た特に疾 患のない男女 12 名 (年齢 20〜 58 歳)のボランティアを 対象とした。ボランティアは, 日常的な運動の有無に かかわらず条件なしで募集を行った。最初に，大腿部 と下腿部に対して, 撮像中心を変えて 2 回, DWIで撮 像を行った. MR 装置は Philips 社製 Ingenia 1.5T で, 表面コイルは 32 チャンネルの phased array coil を使 用した。

撮影条件は SE タイプの EPIを用い, FOV 300x 211, TR $3000 \mathrm{~ms}$, TE $117 \mathrm{~ms}$, スライス枚数は 1 枚, スライス厚 $5 \mathrm{~mm}$, 加算回数 2 回, BW $17.3 \mathrm{~Hz}, \mathrm{EPI}$ factor 49, PI 法の SENSE factor 2, 脂肪抑制法には CHESS 法を選択した。 b 值は 0，5，10，15，20，25， 30，40，50，100，200，400，1000 s/mm² とした。 た，大腿部は FOV 480×240, TE 91 ms, BW $39.3 \mathrm{~Hz}$, EPI factor 25 とし，下腿部は FOV 300×211，TE 117 ms，EPI factor 49 で撮像を行った。ここで，TR は組 織の拡散係数に影響を及ぼさない $3000 \mathrm{~ms}$ 以上を, EPI factor は FOV に応じた最短 TE を設定可能な数 值に設定した ${ }^{11)}$ 。また，下腿部の撮像では，空気によ る磁化率アーチファクトを軽減する目的で, 下腿の間 に米パッドを挟んだ。撮像は, 運動負荷前, 運動負荷 直後, 3, 6,24 時間後の 5 時相で同じ撮像条件で行った.

\section{1-2 運動負荷}

運動負荷として, 階段を使用した昇降動作を採用 し, 運動の程度は被験者の運動能力に応じて変化さ せ，48 段を男性は 10 往復, 女性は 7 往復を目安とし た，昇降時間は任意とした。被験者の 24 時間後の撮 像の際に, 大腿と下腿の感覚的な筋肉痛度を問診し た，評洒法としては，今まで本人が経験した最大の筋 肉痛を 10 , 筋肉痛を感じない状態を 0 として, 現状の 痛みを回答する手法とした，本手法は numerical rating scale に基づいた痛みのスケールの表現法であり, 痛みの評価として感度が高いことが報告されてい $3^{12)}$.

\section{1-3 画像解析}

得られた各 $\mathrm{b}$ 值の DWI の大腿筋と腓腹筋に円形 ROI を設定し，信号値を測定した，ROI の大きさは大 
腿部では $210 \mathrm{~mm}^{2}$, 下腿部では $370 \mathrm{~mm}^{2}$ とし, 大血管 を含まないように設定を行った(Fig. 2).

各 $\mathrm{b}$ 值の信号值から, 山梨大学作成の計算ソフト ${ }^{13)}$ を用いて IVIM の指標である $D^{*}$ ，f， および拡散係数 の指標である diffusion coefficient(DC), apparent diffusion coefficient (ADC)を算出した.

12 名の大腿部および下腿部の運動負荷前, 運動負荷 直後, 3, 6, 24 時間後の各 5 時相での上記指標に対し, Kruskal-Wallis の H 検定 (デー夕形式) で多重比較す るとともに, Mann-Whitneyの統計解析により有意差 検定を行った。なお，統計解析ソフトはStat Mate V （株式会社アトムズ，東京）を使用した．

\section{2. 結 果}

各 $\mathrm{b}$ 值に抢ける下腿の筋肉内の DWI の信号強度 を, Fig. 3 に示す. b 值が 0-50 s/mm $\mathrm{mm}^{2}$ 以下の灌流領 域において, 運動後の補間カーブの急激な減少がみら れた. Figure 4〜7は大腿笳の IVIM 指標である D*, $\mathrm{f}$ ，そして拡散係数を示す $\mathrm{ADC}$ と DC の 15 名の数值 の箱ひげ図である. IVIM の指標である $\mathrm{D}^{*}$ は, 運動 前と比較し運動直後は中央值で上昇がみられたが, 運 動 3 時間後では減少した。その後 6, 24 時間後と中央 值は上昇した。同様に, $\mathrm{f}$ も運動前と比較し運動直後 は有意に上昇し，運動 3 時間後では有意に減少し，そ の後は上昇した，拡散係数である ADC は運動前と比 較し運動直後で有意に上昇し, 3 時間後で有意に減少 した. 6 時間後では上昇し， 24 時間後は運動前と比較
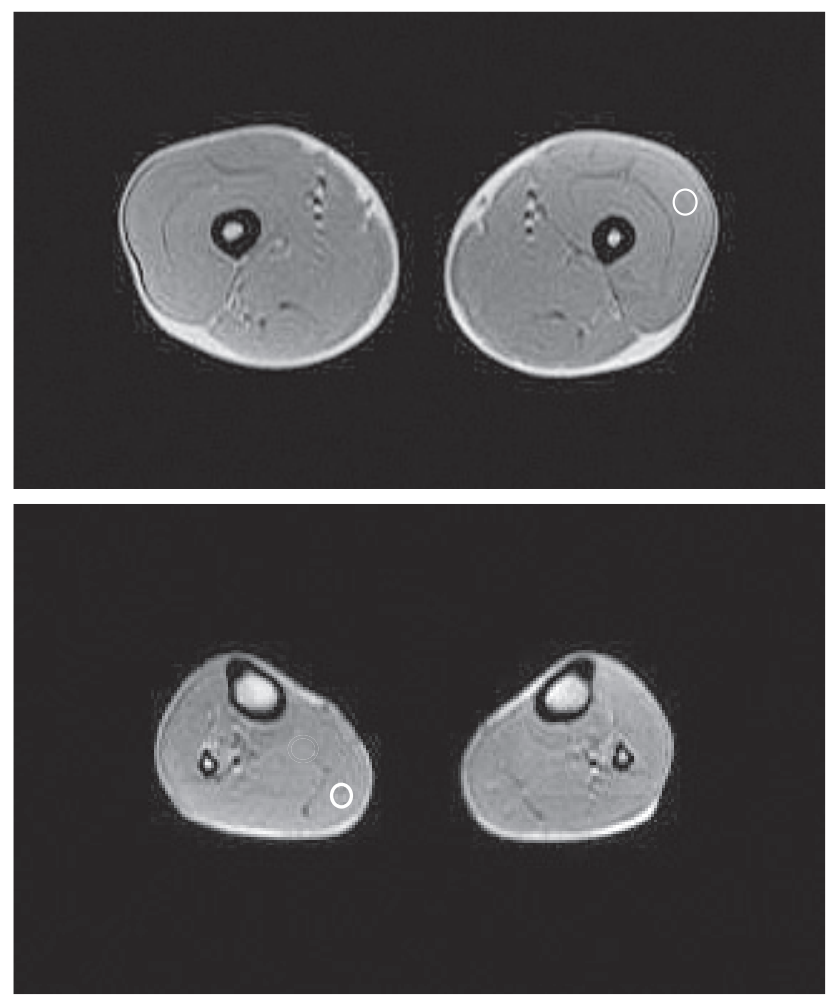

Fig. 2 (a) Setting position of ROI on the thigh muscle (b) Setting position of ROI on the gastrocnemius muscle

a

b

して，ADC 值に有意な上昇がみられた，DCにおいて も同様な傾向がみられたが有意差はみられなかった。

下腿についても, 大腿と同様の結果が得られた。 腓腹筋および大腿筋における各指標の中央値を

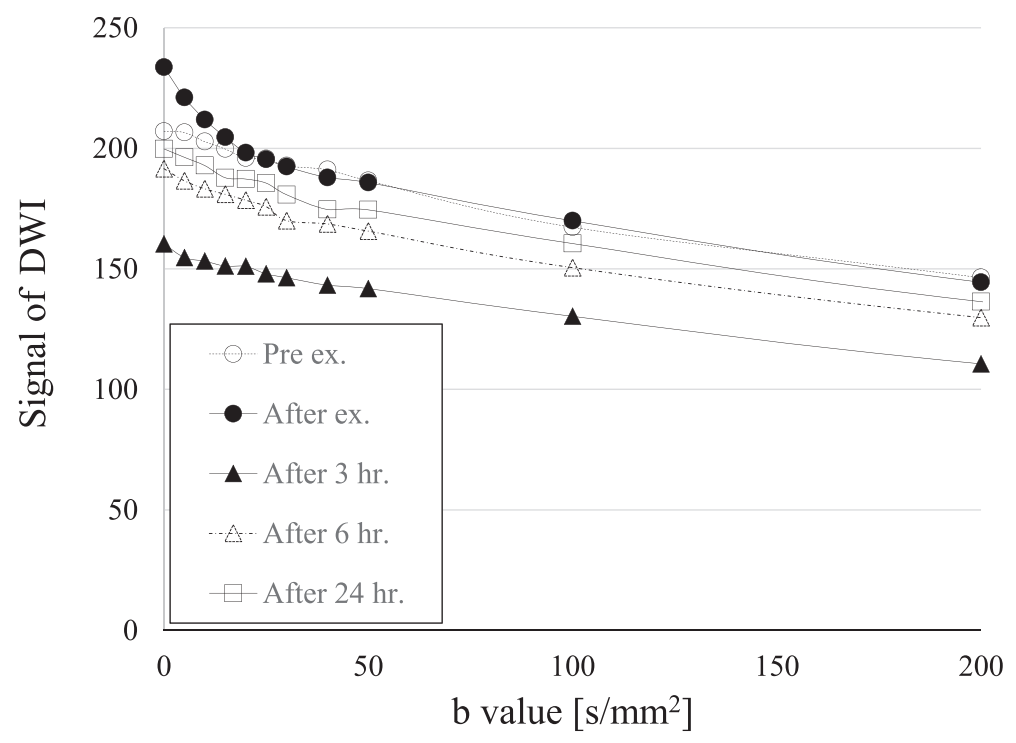

Fig. 3 Signal of DWI for thigh muscle relative to multi-b values before and after exercise.

Signal attenuation was shown immediately after exercise in IVIM region with $\mathrm{b}$ value less than $50 \mathrm{~s} / \mathrm{mm}^{2}$. 


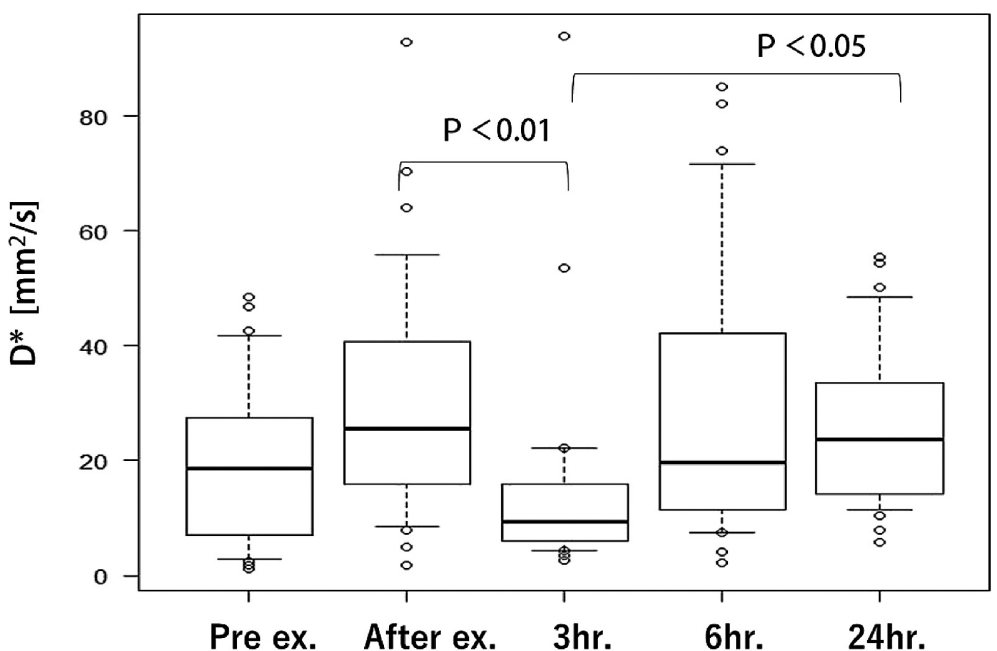

Fig. 4 The $D^{*}$ values at before and after exercise of the thigh muscle.

The $\mathrm{D}^{*}$ values significantly increased after exercise and decreased 3 hours later.

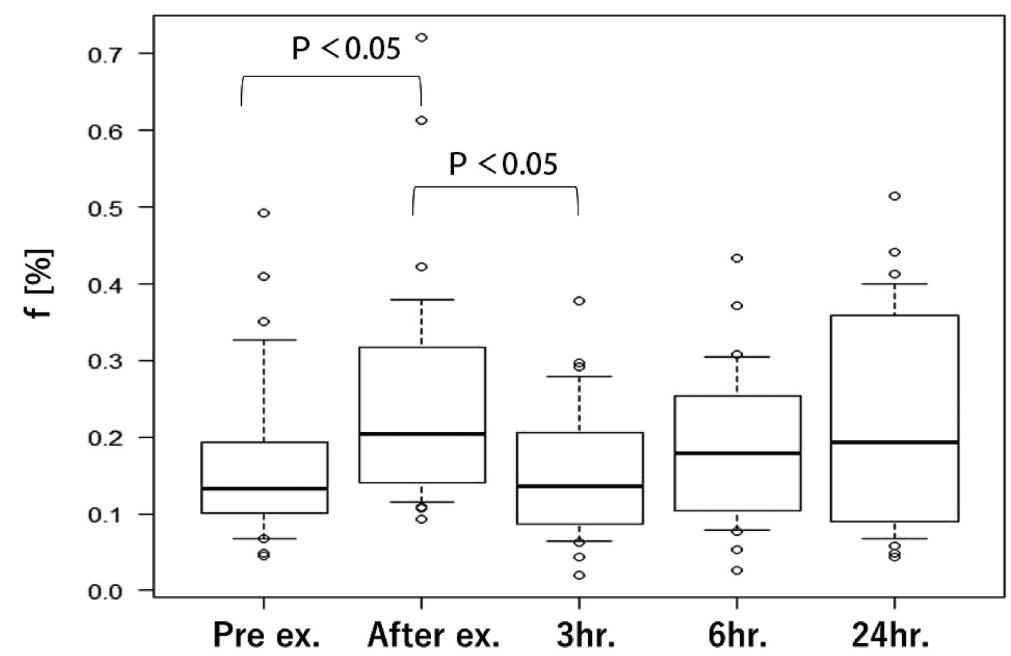

Fig. 5 The $f$ values at before and after exercise of the thigh muscle.

The $\mathrm{f}$ values increased after exercise and decreased 3 hours later and increased again in 24 hours later.

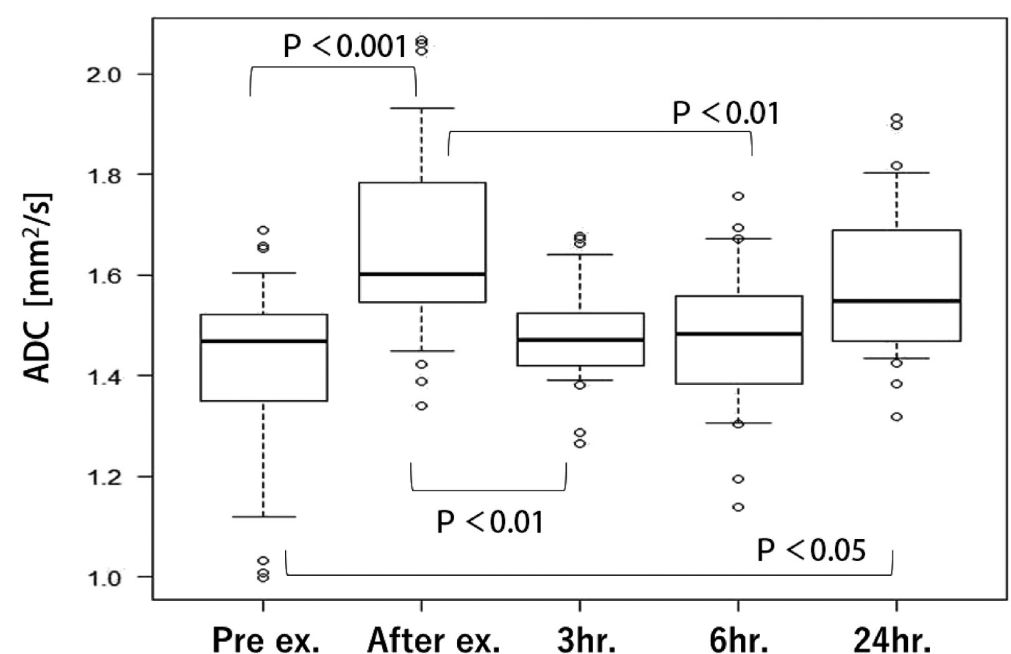

Fig. 6 The ADC values at before and after exercise of the thigh muscle. The ADC showed the tendency similar to the f value and the $\mathrm{D}^{*}$ value. 


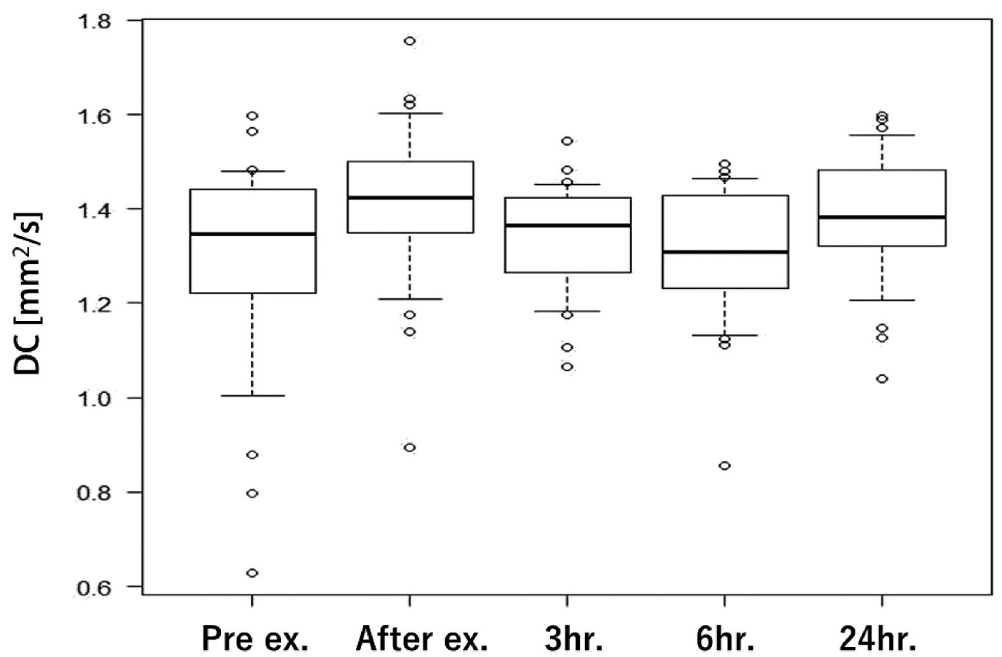

Fig. 7 The DC values at before and after exercise of the thigh muscle. The DC showed a similar tendency too, but there was not a significant difference.
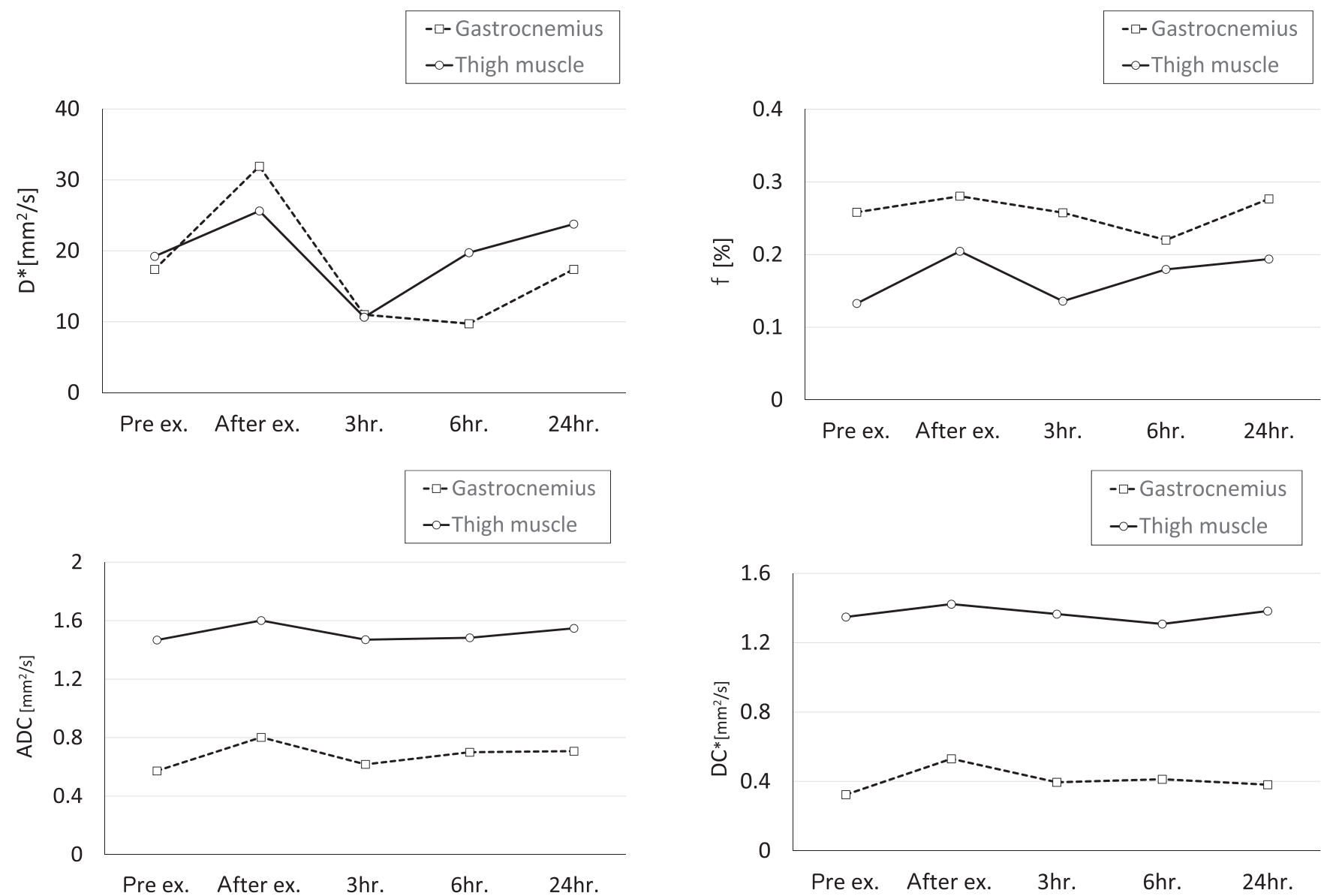

Fig. 8 (a) The median of $\mathrm{D}^{*}$ values for thigh and gastrocnemius muscle before and after exercise and the elapsed time

(b) The median of f-values for thigh and gastrocnemius muscle before and after exercise and the elapsed time

(c) The median of ADC values for thigh and gastrocnemius muscle before and after exercise and the elapsed time

(d) The median of DC values for thigh and gastrocnemius muscle before and after exercise and the elapsed time

\begin{tabular}{l|l}
$a$ & $b$ \\
\hline$c$ & $d$
\end{tabular}

Fig. 8 に示す. IVIM の指標である $\mathrm{D}^{*} お よ ひ ゙ \mathrm{f} は$ 運 動前から運動直後にかけて増加し，その後は 3 時間後 では減少するが 24 時間後に再び上昇する傾向がみら
れた。また，拡散係数である $\mathrm{ADC}$ および DCにおい ても同様の傾向がみられ，各指標の中央值を経過時間 ごとに棒グラフにした結果はどの指標においても運動 
前から運動直後にかけて増加し，その後減少する傾向 となった。

24 時間後に問診した筋肉痛の感覚度と下腿の腓腹 筋および大腿筋の $D^{*}, \mathrm{f}, \mathrm{ADC}, \mathrm{DC}$ の 6 時間後から 24 時間後の指標の差の相関係数を Table に示す。下 腿においては相関がみられなかったが，大腿ではどの 指標に执いても筋肉痛の程度が増加するにつれて差が 大きくなる傾向がみられた，特に相関係数の高かった D*および ADCについて， 6 時間後から 24 時間後の 数値を減算した值と筋肉痛の感覚度を散布図に表した (Fig. 9, 10).

\section{3. 考 察}

毛細血管は, 血液中の酸素や栄養素を組織内に送り 込み, 逆に老廃物を受け取るという循環器系の最も基 本となる役割を果たす血管である，そのため，毛細血 管は人体の健康と密に関係して扮りその重要性が注目 されている，毛細血管は加齢とともに減少し，メカニ ズムは不明であるが運動によって増加するということ がわかっており，近年毛細血管増加のための運動法の 検討なども多くの研究が行われている ${ }^{10)}$. 毛細血管の 血流量を部位ごとに評価することが可能となれば，今 後多くの研究へ貢献することができると考える，表在 性の毛細血管血流量は, 光コヒーレンストモグラフィ $(\mathrm{OCT})^{14)}$ や光学顕微鏡による手法が報告されている が, 体内組織内の毛細血管血流量の評価は現状では困 難である. IVIM は体内組織の灌流情報を表現するこ とが可能であるため, その性質を利用して運動負荷に よる下肢筋肉内の毛細血管血流を経時的に評価を行う ことを本研究の目的とした。

結果として，灌流指標である $\mathrm{D}^{*}$ および $\mathrm{f}$ は，運動 前と比較し運動後で中央值の増加がみられ，また運動 後と比較して 3 時間後で減少がみられたため, 運動に よって毛細血管血流量が増加し, 時間経過とともに減 少したと考える。これらの数値変化は筋肉の炎症によ る $\mathrm{T}_{2}$ 值の影響も無視できないが, 運動直後の変化で あることや $\mathrm{D}^{*}$ が $\mathrm{T}_{2}$ shine through の影響を受けない ことから，毛細血管血流量が有意と考えた。

また各数值が 24 時間後に再び上昇し, 被験者の筋 肉痛の感覚度と相関があったことから, 毛細血管血流 量の増加が筋肉痛の原因と関係していることが示唆さ れた，筋肉痛の原因は現在も解明されていないが，過 去には, 運動によって生じる乳酸の一部が筋肉中の毛 細血管に長時間残存し，筋肉への酸素供給を阻害する ため鈍痛を引き起こすという説があったが, 乳酸値と の関連が少ないことから否定されている ${ }^{10)}$. 筋肉の一
Table Correlation coefficients between 6 and 24 hours with the muscle ache at 24 hours later for the thigh and gastrocnemius muscle of four indexes

\begin{tabular}{lcc}
\hline \hline & Gastrocnemius & Thigh muscle \\
\hline$\Delta \mathrm{D}^{*}\left(\mathrm{~mm}^{2} / \mathrm{s}\right)$ & 0.1152 & 0.4869 \\
$\Delta \mathrm{f}(\%)$ & -0.2642 & 0.3572 \\
$\Delta \mathrm{ADC}\left(\mathrm{mm}^{2} / \mathrm{s}\right)$ & -0.3543 & 0.5838 \\
$\Delta \mathrm{DC}\left(\mathrm{mm}^{2} / \mathrm{s}\right)$ & -0.2211 & 0.4203 \\
\hline
\end{tabular}

次的損傷や炎症の説が有力であるが，これも解明され ていない，大腿では相関がみられたのに対し，下腿の 腓腹筋では相関がみられなかったこともこれらの要因 や運動負荷の方法などが関係すると考えられ，未だ明 確にはなっていない筋肉痛のメカニズムと関係づけて その原因を明らかにすることが今後の検討課題として 挙げられる. また, 今回は ROI を筋肉中心に 1 カ所 設定して解析を行っているが複数の ROI やマッピン グ解析した結果も同様に検討していきたい.しかし, 今回の研究によって, 毛細血管血流量と筋肉痛の相関 があったことは, 炎症等の血流量の増加を示唆するも のである.

また，毛細血管血流量のみでなく，拡散指標である $\mathrm{ADC}$ や DC も運動前と比較し運動直後で有意に上昇 し, 3 時間後で減少し, 24 時間後は 6 時間後と比較し て，中央值で上昇がみられた。これらは，運動による 細胞内の細胞間腔の拡大と運動後の縮小を示している と考える.

これら原因は現状においては明確ではないが, 詳細 なメカニズムは IVIM による毛細血管の血流量と DWIによる細胞間隙の病理的な情報を得ることによ り, 筋肉の疲労過程や筋肉痛の軽減等, 今後更にス ポーツ医学に貢献できるのではないかと考える.

\section{4. 結 語}

IVIM によって運動前後の筋肉内の継時的変化を評

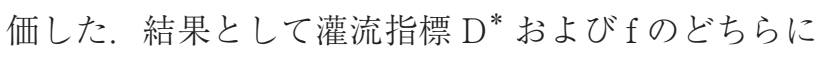
おいても運動後に上昇しその後減少し, 再び上昇する 傾向がみられた，これらは，筋肉の毛細血管血流を反 映していると考える。また，拡散指標である ADC お よび DC も運動前後および 24 時間後の筋肉痛との関 連も示唆されたことから, 細胞間隙情報を反映したも のと予想される，今後，MRIのDWIによるこれらの 情報を解析することにより, 更なるスポーツ医学への 貢献を期待する. 


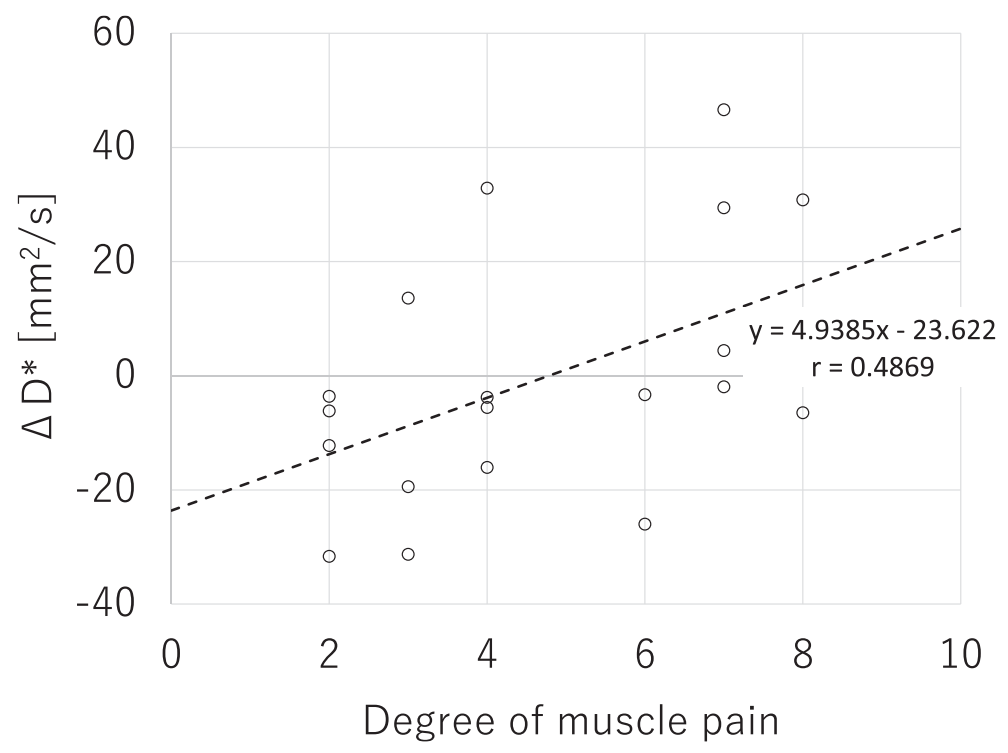

Fig. 9 The correlation with $\mathrm{D}^{*}$ difference between 6 and 24 hours and the muscle ache at 24 hours later for the thigh muscle. The coefficient of correlation was 0.4896 .

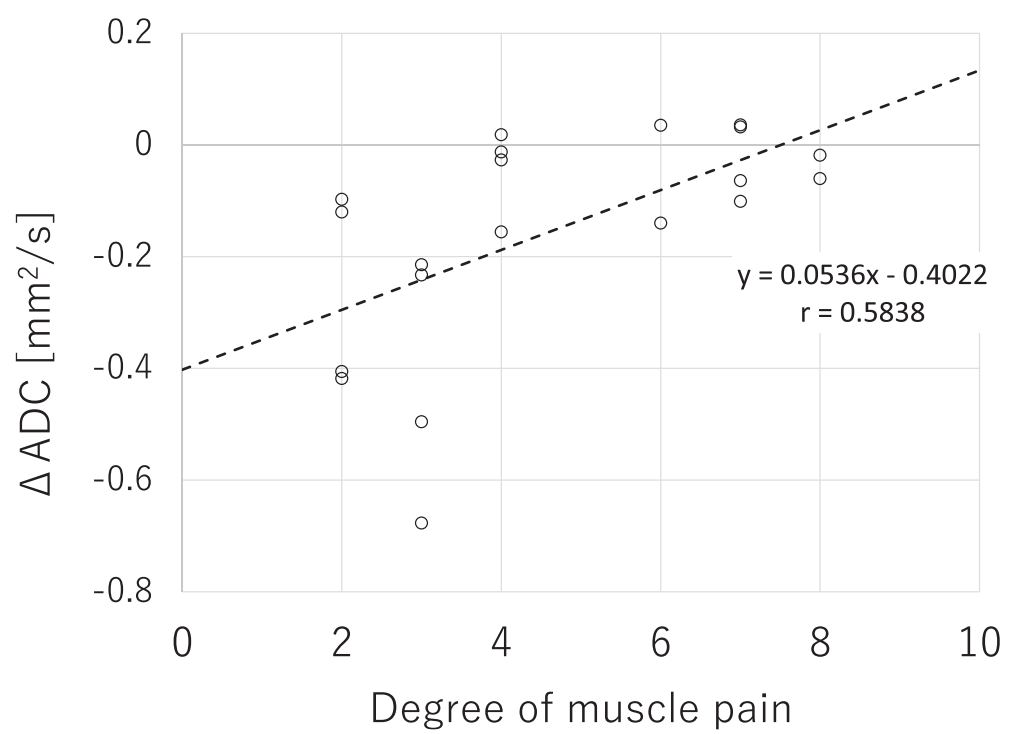

Fig. 10 The correlation with ADC difference between 6 and 24 hours and the muscle ache at 24 hours later for the thigh muscle.

The coefficient of correlation was 0.5838 .

\section{謝 辞}

本研究にボランティアとしてご協力いただいた，本 学教員および学部生の皆様方に深謝いたします。ま た，研究でご指導いただいた土井邦雄元学長はじめ教
員の先生方に感謝申し上げます。

また，本研究の要旨は第 45 回日本放射線技術学会 秋季学術大会 $(2017$ 年, 広島)にて発表した。

\section{参考文献}

1) Le Bihan D, Breton E, Lallemand D, et al. Separation of diffusion and perfusion in intravoxel incoherent motion MR imaging. Radiology 1988; 168(2): 497-505.
2) Ichikawa $S$, Motosugi $U$, Ichikawa $T$, et al. Intravoxel incoherent motion imaging of focal hepatic lesions. J Magn Reson Imaging 2013; 37(6): 1371-1376. 
3) Lewin M, Fartoux L, Vignaud A, et al. The diffusion-weighted imaging perfusion fraction $\mathrm{f}$ is a potential marker of sorafenib treatment in advanced hepatocellular carcinoma: a pilot study. Eur Radiol 2011; 21(2): 281-290.

4) Ichikawa $S$, Motosugi $U$, Ichikawa $T$, et al. Intravoxel incoherent motion imaging of kidney: alterations in diffusion and perfusion in patients with renal dysfunction. Magn Reson Imaging 2013; 31(3): 414-417.

5) Shinmoto H, Tamura $C$, Soga $S$, et al. An intravoxel incoherent motion diffusion-weighted imaging study of prostate cancer. AJR Am J Roentgenol 2012; 199(4): W496-500.

6) Federau C, Meuli R, O'Brien K, et al. Perfusion measurement in brain gliomas with intravoxel incoherent motion MRI. AJNR Am J Neuroradiol 2014; 35(2): 256-262.

7) Liu $\mathrm{C}$, Liang $\mathrm{C}$, Liu $\mathrm{Z}$, et al. Intravoxel incoherent motion (IVIM) in evaluation of breast lesions: comparison with conventional DWI. Eur J Radiol 2013; 82(12): e782-789.

8) Lee EY, Hui ES, Chan KK, et al. Relationship between intravoxel incoherent motion diffusion-weighted MRI and dynamic contrast-enhanced MRI in tissue perfusion of cervical cancers. J Magn Reson Imaging 2015; 42(2): 454-459.

9) Gute D, Laughlin MH, Amann JF. Regional changes in capillary supply in skeletal muscle of interval-sprint and lowintensity, endurance-trained rats. Microcirculation 1994; 1(3): 183-193.

10）八田秀雄．乳酸と運動生理・生化学一エネルギー代謝の 仕組み一。東京：市村出版 2010 .

11) Ogura A, Hayakawa $K$, Miyati $T$, et al. Imaging parameter effects in apparent diffusion coefficient determination of magnetic resonance imaging. Eur J Radiol 2011; 77: 185-188.

12) Scott J, Huskisson EC. Graphic representation of pain. Pain 1976; 2(2): 175-184.

13）山梨大学医学部放射線科. MRI 拡散強調画像の新たな展 開: IVIM の定量 化. http://yamarad.umin.ne.jp/ivim/simplex.html (Accessed 2017.9.30).

14) Srinivasan VJ, Radhakrishnan H, Lo EH, et al. OCT methods for capillary velocimetry. Biomed Opt Express 2012; 3(3): 612629. 